\title{
PERBAIKAN PRODUKTIVITAS KAMBING KACANG MELALUI PELATIHAN PEMBUATAN PAKAN SILASE BAGI WARGA DI KECAMATAN BONE PANTAI KABUPATEN BONE BOLANGO
}

\author{
Fahrul Ilham ${ }^{1)}$, Muhammad Mukhtar ${ }^{2)}$ \\ 1,2) Program Studi Peternakan, Universitas Negeri Gorontalo \\ E-mail : fahrulilham82@ung.ac.id
}

\begin{abstract}
ABSTRAK
Silase merupakan hijauan pakan ternak yang disimpan dalam keadaan segar di dalam silo dan mengalami proses fermentasi sehingga pakan menjadi awet. Tujuan kegiatan Pengabdian Pada Masyarakat (PPM) ini adalah meningkatkan pengetahuan dan keterampilan warga desa di Kecamatan Bone Pantai dalam membuat pakan silase. Pengabdian ini telah dilaksanakan di Desa Lembah Hijau dan Tolotio, Kecamatan Bone Pantai, Kabupaten Bone Bolango. Metode yang digunakan adalah pembelajaran dalam bentuk pemberian teori dan simulasi kepada anggota kelompok sasaran dan selanjutnya praktek secara langsung pengawetan hijauan pakan ternak bersama mahasiswa peserta KKN-PPM dan anggota kelompok pengelola pembibitan kambing kacang. Kegiatan ini dilakukan selama 40 hari (Juli-Agustus 2017) sejak persiapan alat dan bahan, pelaksanaan pelatihan, evaluasi kualitas fisik silase, dan pemberian silase kepada kambing kacang. Bahan utama pembuatan silase adalah daun jagung segar (70\%) dan gamal dan lamtoro (30\%). Pengujian kualiatas silase dilakukan secarafisik dengan kriteria bau/wangi, rasa, warna, tekstur, dan pH. Hasil yang diperoleh terlihat selama kegiatan pelatihan, warga desa cukup antusias mengikuti semua tahap kegiatan sejak persiapan hingga pemberian pakan silase pada kambing kacang. Seluruh tahap kegiatan PPM telah selesai dilaksanakan dengan tingkat capaian adalah $100 \%$. Hasil pengujian terhadap kualitas silase yang dibuat diperoleh bau seperti buah-buahan dan sedikit asam, sangat wangi dan terdorong untuk mencicipinya; apabila dicoba digig it manis dan terasa asam seperti yoghurt/yakult; warna hijau kekuning-kuningan; Kandungan airnya terasa sedikit banyak tetapi tidak terasa basah, dan apabila ditangan dicuci bau wanginya langsung hilang, pH silase adalah 4,3 dan termasuk dalam kategori baik
\end{abstract}

Kata Kunci: Produktivitas, Kambing Kacang, Silasee

\section{PENDAHULUAN}

Ternak kambing merupakan hewan ruminansia yang tersebar hampir di seluruh wilayah Indonesia. Populasi ternak kambing di Indonesia sebagian besar didominasi oleh kambing kacang yang merupakan kambing asli Indonesia dan kambing Peranakan Etawah (PE) yang merupakan hasil persilangan antara kambing etawah dari India dan kambing kacang asli Indonesia. Kambing kacang memiliki ciri bentuk badannya kecil sedangkan kambing etawah tubuhnya lebih besar dari kambing kacang (Subandriyo, 2005).

Populasi kambing di Provinsi Gorontalo tahun 2014 adalah 82.205 ekor dan 4.976 ekor diantaranya berada di Kabupaten Bone Bolango (BPS, 2014). Hasil penelitian Ilham, (2014) menyatakan kambing yang banyak dipelihara di Provinsi Gorontalo adalah kambing kacang, kambing PE, dan keturunan dari hasil persilangan antara keduanya (Ilham, 2014).

Peternak kambing kacang di beberapa 
wilayah Indonesia khususnya di Provinsi Gorontalo umumnya memelihara kambing kacang dengan sangat sederhana yaitu siang dilepas untuk mencari pakan sendiri dan malam baru dikandangkan (bagi yang memiliki kandang). Sistem pemeliharaan seperti ini menyebabkan peternak kesulitan untuk melakukan kontrol terhadap pakan yang dikonsumsi apakah sudah sesuai kebutuhan atau tidak. Pada kondisi lingkungan yang memiliki pakan yang berlimpah, hal ini tidak menjadi masalah sebab pakan tersedia sepanjang waktu dan ternak kambing bebas untuk mengkonsumsi pakan sesuai keinginannya. Kondisi alam disebagian besar wilayah Gorontalo yang tidak mampu mendukung untuk beternak kambing secara intensif menyebabkan produktivitas kambing kacang cukup rendah sehingga sangat sulit untuk memenuhi kebutuhan para penggemar daging kambing maupun industri-industri pengolahan daging.

Salah satu alternatif untuk mengatasi kekurangan pakan terutama di musim kemarau adalah dengan melakukan pengawetan pakan. Silase merupakan pakan yang diawetkan dengan cara difermentasi dalam silo pada kondisi anaerob. Silase yang komplit adalah silase yang ketika dibuat telah mengandung semua nutrisi yang dibutuhkan ternak sehingga peternak tidak perlu lagi menyiapkan pakan tambahan untuk menutupi kekurangan nutrisinya.

Kambing kacang yang dipelihara warga desa di Kecamatan Bone Pantai umumnya dipelihara secara tradisional sehingga produktivitasnya cukup rendah. Pengetahuan warga tentang pengawetan pakan yang masih sangat minim dan ketidakmampuan untuk menyiapkan pakan setiap hari bila kambing dikandangkan menjadi alasan beberapa warga peternak kambing kacang melepaskan ternaknya untuk mencari pakan sendiri. Berdasarkan permasalahan tersebut maka kegiatan pengabdian ini dilaksanakan di Desa Lembah Hijau dan Tolotio dengan harapan pengetahuan warga desa tentang silase bertambah dan tidak perlu lagi setiap hari mencari pakan sebab sudah ada cadangan pakan untuk beberapa minggu bahkan beberapa bulan kedepan.

\section{METODE PELAKSANAAN}

Pengabdian Pada Masyarakat (PPM) berupa pembuatan silase ini dilaksanakan di Kecamatan Bone Pantai, tepatnya di Desa Lembah Hijau dan Tolotio selama 2 bulan. Peserta kegiatan adalah warga desa Lembah Hijau dan Desa Tolotio Kecamatan Bone Pantai bersama mahasiswa Kuliah Kerja Nyata-Pembelajaran Pada Masyarakat (KKNPPM).

Metode yang digunakan dalam melakukan pemberdayaan warga desa didahului dengan pemberian teori kepada warga desa yang menjadi sasaran dan diikuti dengan praktek secara langsung pembuatan silase. Bahan utama silase yang dibuat adalah daun jagung (70\%) dan daun gamal dan 
lamtoro (30\%), dedak padi, molases, Effective Microorganism (EM)-11, dan air. Keseluruhan bahan dicampur dan dimasukkan kedalam silo agar mengalami fermentasi selama 1 minggu. Beberapa peralatan yang digunakan antara lain sekop, parang, terpal, tong biru, ember. Seminggu setelah proses fermentasi, kualitas fisik silase dievaluasi apakah telah memenuhi kriteria silase yang baik. Setelah evaluasi, silase selanjutnya diberikan kepada ternak kambing dengan frekuensi pemberian 2 kali yaitu pada pagi dan sore hari.

\section{HASIL DAN PEMBAHASAN}

\section{Bahan Pembuatan Silase}

Silase adalah pakan dari hijauan segar yang diawetkan dengan cara fermentasi anaerob dalam kondisi kadar air tinggi (40 - 70\%) oleh bakteri asam laktat, sehingga hasilnya bisa disimpan tanpa merusak zat gizi di dalamnya (Zakariah, 2012 ; Subekti dkk, 2013). Bakteri Asam Laktat (BAL) termasuk bakteri yang menguntungkan sebab dapat dapat menghambat pertumbuhan bakteri pembusuk dan bakteri patogen pada produk pangan serta produk fermentasi (Misgiyarta dan Widowati, 2002). Menurut Fardiaz (1989), BAL mempunyai kemampuan memfermentasi gula menjadi asam laktat dan memproduksi asam secara cepat sehingga pertumbuhan mikroba lain yang tidak diinginkan dapat terhambat.
Prinsip dasar pada pembuatan silase secara garis besar yaitu menghilangkan udara dengan cepat, menghasilkan asam laktat yang membantu menurunkan $\mathrm{pH}$, mencegah masuknya oksigen kedalam silo, menghambat pertumbuhan jamur selama penyimpanan (BPTP Kalteng, 2012).

Bahan utama yang digunakan pada pembuatan silase di Desa Lembah Hijau dan Desa Tolotio adalah jerami jagung, daun gamal, daun lamtoro, dedak, dan molases, Effective Microorganism (EM)11. Pemilihan bahan-bahan ini sebab ketersediaannya cukup banyak disekitar lokasi PPM sehingga mengurangi biaya pengangkutan.

- Pemanfaatan tanaman jagung sebagai bahan utama pembuatan silase disamping ketersediaannya cukup banyak di Gorontalo juga kandungan nutrisi yang dimiliki cukup tinggi untuk kambing kacang. Produksi jagung tahun 2015 di Gorontalo adalah 643.513 ton pipilan kering dengan luas panen sebesar 19.685 hektar (BPS, 2016). Jerami jagung yang digunakan adalah yang masih dalam kondisi segar setelah panen dengan kadar air sekitar $60 \%$.

- Gamal adalah tumbuhan leguminosa yang memiliki pertumbuhan yang cepat 
meskipun dalam kondisi lahan kurang air. Kandungan nutrisi hijauan gamal (G.liricidium sepium) yaitu kadar protein $25,7 \%$, serat kasar 13,3\%, abu 8,4\%, dan BETN 4,0\% (Hartadi dkk, 1993). Ketersediaan gamal di sekitar lokasi Desa Lembah Hijau dan Tolotio cukup banyak sehingga memudahkan selama pembuatan silase.

- Lamtoro (Leucaena leucocephala) merupakan tanaman yang termasuk tanaman kacang-kacangan, berbentuk pohon dan dapat tumbuh dengan tinggi pohon 8-15 meter serta berumur tahunan (17-32 tahun). Tanaman ini tersebar luas di seluruh pelosok pedesaan dan mudah tumbuh hampir di semua tempat yang mendapat curah hujan cukup. Perbanyakan tanaman tersebut dilakukan secara generatif (biji). Penanaman dengan biji menyebabkan tanaman memiliki sistem perakaran yang kuat dan dalam sehingga dapat bertahan untuk jangka waktu yang cukup lama (Mathius, 1993). Lamtoro memiliki zat anti nutrisi mimosin dan asam sianida sehingga sebelum diberikan pada ternak kambing harus dilayukan terlebih dahulu selama beberapa jam. Daun lamtoro mengandung protein kasar 24,2\%, abu 7,5\%, energi metabolisme $2450 \mathrm{kkal} / \mathrm{kg}$, serat kasar $21,5 \%$, kalsium $1,68 \%$, dan posfor 0,21\% (D’Melo dan Thomas, 1992). Seperti halnya gamal, ketersediaan lamtoro di sekitar lokasi Desa Lembah Hijau dan Tolotio cukup banyak sehingga memudahkan selama pembuatan silase.

- Dedak padi (rice bran) merupakan sisa dari penggilingan padi dengan kandungan serat kasar berkisar 6-27\% (Putrawan dan Soerawidjaja, 2007). Dedak padi mengandung energi metabolis sebesar $2980 \mathrm{kka} / \mathrm{kg}$, protein kasar $12.9 \%$, lemak $13 \%$, serat kasar $11,4 \%, \mathrm{Ca} 0,07 \%, \mathrm{P}$ tersedia $0,22 \%$, Mg 0,95\% serta kadar air 9\% (National Research Council, 1994 ; Dewan Standarisasi Nasional, 2001). Kandungan energi yang tinggi menyebabkan dedak padi sering digunakan dalam proses fermentasi sebagai sumber makanan mikroorganisme.

- Molases (tetes tebu) merupakan hasil samping dari pengolahan tebu menjadi gula yang masih mengandung gula dan asam-asam organik cukup tinggi. Kandungan sukrosa dalam molases adalah 48-55\% (Sebayang, 2006) sehingga sering digunakan peternak untuk sumber makanan mikrorganisme 
dalam proses pembuatan pakan fermentasi.

- Effective Microorganism (EM)-11 merupakan kultur campuran dari berbagai mikroorganisme fermentatif dan sintetik yang menguntungkan. EM11 mengandung bakteri yang mampu mencerna selulose, pati, gula, protein, lemak khususnya bakteri Lactobastillus Sp (Akmal et al, 2004) sehingga pakan yang difermentasi meningkat kecernaannya.

\section{Cara Kerja}

Silase yang telah dibuat di lokasi PPM memiliki komposisi nutrisi ..... protein kasar dasar bahan kering dan ... Total Digestible Nutrient (TDN) dasar bahan kering. Bahan-bahan penyusun silase yang telah dibuat terdiri atas: jerami jagung $70 \%$, daun gamal dan lamtoro $30 \%$, dedak padi ...\%, molases ..\%, EM11...ml, dan air ..\%. Sumber hijauan (jerami jagung, daun gamal, daun lamtoro) terlebih dahulu dilayukan selama 1 hari pada ruang terbuka yang beratap selanjutnya dipotong-potong $3-5 \mathrm{~cm}$ dengan menggunakan chopper dan parang. Pemotongan bertujuan agar seluruh bahan hijauan dapat tercampur secara merata dan padat ketika telah dimasukkan dalam silo. EM-11 dimasukkan kedalam air yang telah tercampur dengan molases dan diaduk rata. Masing-masing bahan hijauan dan dedak padi selanjutnya dicampur dan diaduk sampai merata sambil dipercik dengan campuran air molases dan EM-11. Hasil campuran ransum tersebut dimasukkan ke dalam silo, dipadatkan, ditutup rapat dan diinkubasi dalam kondisi anaerob selama satu minggu dibawah naungan. Seminggu setelah fermentasi, silase dibuka dan dilakukan evaluasi keberhasilan berdasarkan penampilan fisik kualitatif. Sebelum diberikan ke ternak kambing, silase terlebih dahulu dianginanginkan agar amoniak yang terbentuk selama proses fermentasi menguap keudara dan kambing tidak keracunan.

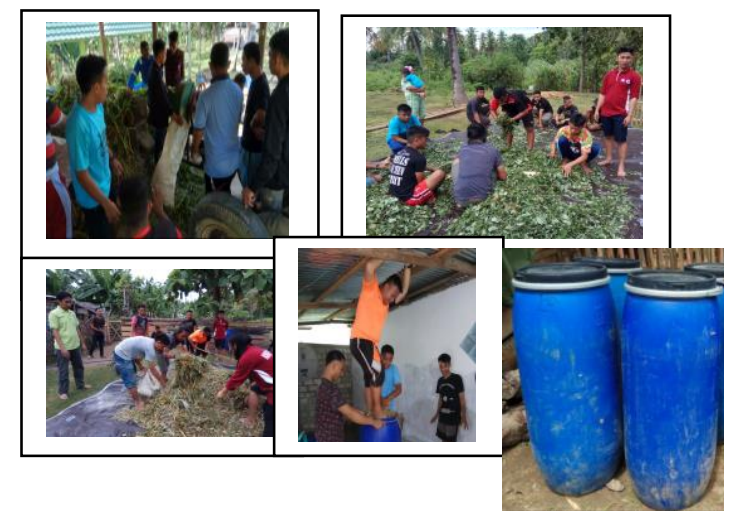

Gambar 1 Daun jagung (kiri atas) dan legum gamal dan lamtoro (kanan atas) dipotong agar mudah dicampur dan dimasukkan ke dalam silo. Keseluruhan bahan silase daun jagung, gamal, lamtoro, dan dedak dicampur dan dimasukkan ke dalam silo sambil dipadatkan dengan cara diinjak dan ditutup rapat (bawah) 


\section{Evaluasi kualitas fisik silase}

Evaluasi terhadap kualitas silase yang telah difermentasi selama seminggu didasarkan pada kondisi fisik silase setelah silo dibuka dan diangin-anginkan. Kriteria yang digunakan berdasarkan indikatorindikator dari silase yang telah dilakukan oleh Muhakka, dkk (2007) diantaranya bau, rasa, warna, dan tekstur. Indikator lainnya adalah $\mathrm{pH}$ yang diketahui dengan menggunakan alat $\mathrm{pH}$ meter. Jumlah panelis yang digunakan untuk menguji kualitas fisik silase adalah 10 orang yang sebelumnya telah diberikan pelatihan cara penilaian.

Tabel 1. Hasil Evaluasi Kualitas Fisik Silase Pada PPM di Kecamatan Bone Pantai Kabupaten Bone Bolango

\begin{tabular}{|c|c|c|c|}
\hline $\begin{array}{l}\text { Indikator } \\
\text { Penilaian }\end{array}$ & $\begin{array}{c}\text { Nilai } \\
\text { Maksimal }\end{array}$ & $\begin{array}{c}\text { Penjelasan Indikator } \\
\text { Penilaian }\end{array}$ & $\begin{array}{c}\text { Nilai } \\
\text { yang } \\
\text { diperoleh }\end{array}$ \\
\hline $\begin{array}{c}\text { Bau/ } \\
\text { Wangi }\end{array}$ & 25 & $\begin{array}{l}\text { 1. Bau sangat wangi } \\
\text { seperti buah-buahan, } \\
\text { sedikit asam, dan } \\
\text { terdorong untuk } \\
\text { mencicipi (25) } \\
\text { 2. Bau asam wangi, } \\
\text { dan terdorong ingin } \\
\text { mencicipi (20) } \\
\text { 3. Bau asam dan wangi } \\
\text { sama sekali tidak } \\
\text { terasa (10) } \\
\text { 4. Bau yang tidak } \\
\text { sedap seperti } \\
\text { kompos, memiliki } \\
\text { jamur }(0)\end{array}$ & 22 \\
\hline Rasa & 25 & $\begin{array}{l}\text { 1. Rasa manis dan } \\
\text { terasa asam seperti } \\
\text { y oghurt/y akult } \\
\text { apabila dicoba } \\
\text { digigit (25) } \\
\text { 2. Rasa sedikit asam } \\
\text { (20) } \\
\text { 3. Tidak ada rasa (10) } \\
\text { 4. Rasa yang tidak } \\
\text { sedap, tidak ada } \\
\text { dorongan untuk } \\
\text { mencoba (0) }\end{array}$ & 18,5 \\
\hline Warna & 25 & $\begin{array}{l}\text { 1. Hijau kekuning- } \\
\text { kuningan (25) agak } \\
\text { 2. Coklat } \\
\text { kehitam-hitaman } \\
\text { (10) } \\
\text { 3. Hitam, mendekati } \\
\text { warna kompos (0) }\end{array}$ & 25 \\
\hline
\end{tabular}

\begin{tabular}{|c|c|c|c|}
\hline Tekstur & 25 & $\begin{array}{l}\text { 1. Kering, tetapi } \\
\text { apabila dipegang } \\
\text { terasa lembut dan } \\
\text { empuk Apabila } \\
\text { menempel ditangan } \\
\text { karena bauny a yang } \\
\text { wangi. tidak } \\
\text { dicucipun tidak apa- } \\
\text { apa (25) } \\
\text { 2. Kandungan airnya } \\
\text { terasa sedikit banyak } \\
\text { tetapi tidak terasa } \\
\text { basah. Apabila } \\
\text { tangan dicuci bau } \\
\text { wanginy a langsung } \\
\text { hilang (10). } \\
\text { 3. Kandungan airnya } \\
\text { banyak, terasa basah } \\
\text { sedikit (becek) bau } \\
\text { yang menempel } \\
\text { ditangan harus } \\
\text { dicuci dengan sabun } \\
\text { supaya baunya } \\
\text { hilang (0) }\end{array}$ & 17,5 \\
\hline $\begin{array}{l}\text { Total } \\
\text { nilai }\end{array}$ & 100 & & 83 \\
\hline
\end{tabular}

Berdasarkan hasil pengamatan dengan 4 indikator penilaian yang digunakan (Tabel 1) total skor rata-rata yang diperoleh dari keseluruhan indikator adalah 83 dari 100 skor maksimal yang harus didapatkan.

Indikator bau asam yang dihasilkan pada silase disebabkan karena pada proses pembuatan silase bakteri anaerob aktif bekerja menghasilkan asam organik. Pada awal proses pembentukan silase (ensilase), bakteri yang banyak berperan adalah bakteri aerob, namun ketika oksigen telah habis dipakai untuk bernapas maka kondisi dalam silo menjadi anaerob, selanjutnya yang banyak berperan adalah bakteri anaerob yaitu bakteri asam laktat. Penambahan inokulum EM-11 yang banyak mengandung bakteri salah satunya adalah Lactobacillus $s p$ yang mampu mencerna selulose, pati, gula, protein, dan lemak dalam hijauan pakan menyebabkan bakteri asam laktat akan tumbuh semakin subur dan kondisi dalam silo juga akan semakin asam. Bau wangi yang timbul pada silase disebabkan adanya fermentasi asam propionat sehingga menimbulkan wangi yang 
menyengat (Saun dan Heinrichs, 2008). Demikian juga pada indikator rasa ketika dicoba terasa asam sedikit dan agak manis disamping penyebabnya karena bakteri asam laktat juga disebabkan adanya bahan tambahan molases yang diencerkan bersama EM-11.

Berdasarkan indikator warna silase pada Tabel 1, warna silase yang didapatkan adalah hijau kekuningan yang menandakan bahwa kualitas silase yang dibuat termasuk kedalam kategori sangat baik. Reksohadiprodjo (1988) menyatakan perubahan-perubahan yang terjadi dalam tanaman karena proses respirasi aerobik yang berlangsung selama persediaan oksigen masih ada, sampai gula tanaman habis. Gula akan teroksidasi menjadi $\mathrm{CO} 2$ dan air, dan terjadi panas hingga temperatur naik. Bila temperatur tak dapat terkendali, silase akan berwarna coklat tua sampai hitam. Hal ini menyebabkan turunnya nilai makanan, karena banyak sumber karbohidrat yang hilang dan kecernaan protein turun, yaitu pada temperatur $55^{\circ} \mathrm{C}$. Warna coklat pada silase disebabkan karena adanya pigment phatophytin suatu derivat chlorophil yang tak ada magnesiumnya. Pada silase yang baik dengan temperatur yang naik tak terlalu tinggi kadar carotene tak berubah seperti bahan asalnya. Caroten hilang pada temperatur terlalu tinggi.

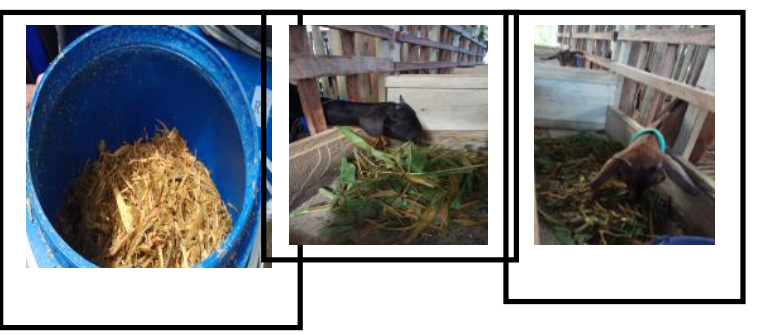

Gambar 2 Silase yang telah mengalami fermentasi selama seminggu (kiri) dan pemberian silase yang dicampur dengan hijauan pakan segar pada kambing kacang di lokasi PPM (tengah \& kanan)

Berdasarkan tekstur, silase yang diperoleh mendapatkan skor 17,5 yang menandakan tekstur silase ketika disentuh dalam kondisi agak kering, lembut, dan terasa empuk sedikit. Silase terlihat agak lembab namun tidak ditemukan jamur dan hal ini dipengaruhi oleh tingginya curah hujan selama fermentasi sementara silo hanya ditempatkan dibawah pohon tanpa ada atap sehingga silo terkena air hujan. Selama proses ensilase terjadi perombakan protein menjadi amonia, asam amino, amida, asam asetat, asam butirat, air. Air yang terbentuk menyebabkan sukar terjadi keadaan anaerob dan dapat menjadi media pertumbuhan jamur sehingga apabila dibiarkan terus dan diberikan ke ternak dapat menimbulkan keracunan (Reksohadiprodjo, 1988).

Hasil pengukuran terhadap $\mathrm{pH}$ silase pada pengabdian ini dengan menggunakan $\mathrm{pH}$ meter didapatkan nila $\mathrm{pH}$ rata rata 4,3 . Nilai $\mathrm{pH}$ yang diperoleh tersebut termasuk kategori baik, sebab kualitas silase berdasarkan nilai pH adalah 3,5 - 4,2 baik sekali, 4,2 - 4,5 baik, 4,5 - 4,8 sedang, > 4,8 buruk (Deptan, 1980). 


\section{Pemberian Silase Pada Kambing}

Berdasarkan evaluasi pada kualitas fisik secara umum silase yang dihasilkan pada kegiatan PPM termasuk dalam kategori baik dan layak dikonsumsi oleh kambing. Berdasarkan pengamatan, kambing kacang yang diberi pakan silase memperlihatkan daya suka (palatabilitas) yang cukup tinggi, terlihat pada pakan yang selalu habis dikonsumsi saat diberikan. Sebelum diberikan ke kambing, silase diangin-anginkan terlebih dahulu selama beberapa menit agar amoniak yang terbentuk selama proses fermentasi dapat hilang. Agar kambing kacang dapat terbiasa dengan silase, maka diawal pemberian silase dicampur dengan hijauan yang masih segar dengan perbandingan $75 \%: 25 \%, 50 \%: 50 \%$, dan $25 \%: 75 \%$ dan diberikan secara bertahap setiap minggu.

\section{KESIMPULAN DAN SARAN}

Berdasarkan hasil dan pembahasan disimpulkan capaian terhadap keseluruhan kegiatan pelatihan pembuatan silase bagi warga desa di Kecamatan Bone Pantai adalah $100 \%$. Silase dari formulasi $70 \%$ jagung dan $30 \%$ daun gamal dan lamtoro dapat menjadi alternatif bagi warga desa setempat dalam menanggulangi kekurangan pakan di musim kemarau. Silase dapat disimpan lebih lama sebagai cadangan makanan sehingga waktu peternak untuk mencari pakan dapat digunakan untuk kegiatan lain.

\section{KEPUSTAKAAN}

Akmal, S. 2004. Fermentasi Jerami Padi Dengan Probiotik Sebagai Pakan Ternak Ruminansia. Jurnal Agrista Vol. 5(3) :280-283

Badan Pusat Statistik (BPS). 2014. Bone Bolango Dalam Angka 2014. Badan Pusat Statistik Kabupaten Bone Bolango. Bone Bolango.

Badan Pusat Statistik (BPS). 2016. Gorontalo Dalam Angka 2016. Badan Pusat Statistik Provinsi Gorontalo. Gorontalo

Balai Pengkajian Teknologi Pertanian (BPTP) Kalimantan Tengah. 2012. Info Teknologi Pertanian: Teknologi Pembuatan Pembuatan Silase Komplit. Kementerian Pertanian. Badan Penelitian dan Pengembangan Pertanian. Balai Pengkajian Teknologi Pertanian Kalimantan Tengah.

Departemen Pertanian (Deptan). 1980. Silase Sebagai Makanan Ternak. Departemen Pertanian. Balai Informasi Pertanian. Laporan Penelitian Ternak. Ciawi, Bogor.

D’Melo dan Thomas. 1992. Hasil Analisis Kimia Daun Lamtoro Mengandung Protein Kasar.

Fardiaz. 1989. Mikrobiologi Pangan. Pusat Antar Universitas Institut Pertanian Bogor. Bogor

Hartadi, H., S. Reksohadiprodjo dan A.D. Tillman. 1993. Tabel Komposisi Pakan Untuk Indonesia. Cetakan III. Gadjah Mada University Press, Yogyakarta

Ilham, F. 2014. Keragaman Fenotip Kambing Lokal Kabupaten Bone Bolango. Prosiding Seminar Nasional dan Workshop Optimalisasi Sumberdaya Lokal pada Peternakan Rakyat Berbasis Teknologi-1 2014. UNHAS Makassar. 9-10 Oktober 2014:41-50

Mathius, I.W. 1993. Tanaman Lamtoro Sebagai Bank Pakan Hijauan Yang Berkualitas Untuk Kambing-Domba. 
Jurnal Wartazoa Vol . 3 No. 1, Pebruari 1993

Misgiyarta dan Widowati. 2002. Seleksi dan identifikasi bakteri asam laktat (BAL) Indegenus. (Prosiding).

Muhakka, A. Fariani, Dan A. Imsya. 2007. Potensi Penyediaan Hijauan Rumput Raja Dengan Pemberian Pupuk Organik Dan Sulfur Serta Pembuatan Silase Sebagai Pakan Ternak Sapi Di Desa Rambutan Kabupaten Banyu Asin. Prosiding Seminar Pembahasan Hasil Kegiatan Iptek Dan Vucer LPM Unsri Tahun 2007. Indralaya, 6-7 Desember 2007

Putrawan, I.D.G.A., dan T.H. Soerawidjaja. 2007. Stabilisasi Dedak Padi Melalui Pemasakan Ekstrusif. Jurnal Teknik Kimia Indonesia. 6 (3) Desember 2007 ; 681- 688.

Reksohadiprodjo, S. 1988. Pakan Ternak Gembala. BPFE, Yogyakarta.

Samples dan McCutcheon. 2000. di dalam Furqaanida, N. 2004. Pemanfaatan Klobot Jagung Sebagai Substitusi Sumber Serat Ditinjau dari Kualitas Fisik dan Palatabilitas Wafer Ransum Komplit untuk Domba. Skripsi. Departemen Ilmu Nutrisi dan Makanan Ternak Fakultas Peternakan Institut Pertanian Bogor, Bogor.

Saun, R.J.V. and A.J. Heinrichs. 2008. Troubleshooting Silage Problems: How To Identify Potential Problem. Proceddings Of The Mid-Atlantic Conference; Pennsylvania, 26 - 26 May 2008. Penn State's Collage. pp. 2 - 10.

Sebayang, F. 2006. Pembuatan Etanol Dari Molase Secara Fermentasi Menggunakan Sel Saccharomyces cerevisiaeyang \begin{tabular}{lll} 
Terimobilisasi & Pada & Kalsium \\
\hline
\end{tabular} Alginat. Jurnal Teknologi Proses. Departemen Kimia, Fakultas MIPA, Universitas Sumatera Utara: 6874. ISSN $1412-7814$

Subandriyo. 2005. Strategi Pemanfaatan Plasma Nutfah Kambing Lokal Dan Peningkatan Mutu Genetik Kambing di Indonesia. Balai Penelitian Ternak,Pusat Penelitian dan Pengembangan Peternakan. Bogor.
Subekti, G., Suwarno., Hidayat, N. 2013. Penggunaan Beberapa Aditif Dan Bakteri Asam Laktat Terhadap Karakteristik Fisik Silase Rumput Gajah Pada Hari Ke14. Jurnal Ilmiah Peternakan 1(3): 835841

Zakariah, M.A. 2012. Teknologi Fermentasi Dan Enzim. "Fermentasi Asam Laktat Pada Silase". Fakultas Peternakan. Universitas Gadjah Mada. Yogyakarta. 